How stable are polymer: PCBM bulk heterojunction solar cells?

Non Peer-reviewed author version

BERTHO, Sabine; HAELDERMANS, Ilse; SWINNEN, Ann; D'HAEN, Jan; LUTSEN, Laurence; MANCA, Jean \& VANDERZANDE, Dirk (2006) How stable are polymer: PCBM bulk heterojunction solar cells?. In: Heremans, Paul L \& Muccini, Michele \& Meulenkamp, Eric A. (Ed.) Organic Optoelectronics and Photonics II. p. 19225-19225..

DOI: $10.1117 / 12.663156$

Handle: http://hdl.handle.net/1942/9662 


\title{
How stable are polymer:PCBM bulk heterojunction solar cells?
}

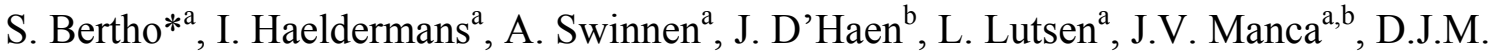 \\ Vanderzande $\mathrm{a}^{\mathrm{a} b}$ \\ ${ }^{\mathrm{a}}$ Instituut voor Materiaalonderzoek, Universiteit Hasselt, Belgium \\ ${ }^{\mathrm{b}}$ IMEC vZw, divisions IMOMEC (Diepenbeek) and MCP (Leuven), Belgium
}

\begin{abstract}
This paper investigates the thermal stability of organic bulk heterojunction solar cells, with a special focus on the thermal ageing of both photovoltaic parameters and morphology of the active layer. The photovoltaic parameters of a set of bulk heterojunction solar cells were determined by IV-characterization and their bulk morphology was investigated with transmission electron microscopy (TEM). A link could be made between the degradation of the short circuit current under a thermal treatment and the corresponding change in bulk morphology. A possible improvement of the thermal stability of bulk heterojunction solar cells is presented through the use of a polymer with higher glass transition temperature.
\end{abstract}

Keywords: organic solar cells, stability, thermal ageing, morphology

\section{INTRODUCTION}

Organic bulk heterojunction solar cells have been considered during the last decade as very promising for future renewable energy generation. At this moment polymer:fullerene bulk heterojunction solar cells have been reported with power conversion efficiencies around $5 \%$ and therefore start to become really useful for introduction in real life applications ${ }^{1}$. The two main issues that are being addressed in this field are improvement of performance and improvement of stability. ${ }^{2,3,4,5,6}$ Concerning this latter, the use of organic solar cells in real life applications requires at least lifetimes in the order of several thousands of working hours. An important environmental parameter related to stability and degradation is temperature. Especially for outdoor applications where solar cells operate in full sunlight, they have to resist fairly high temperatures (up to $75^{\circ} \mathrm{C}$ ).

Recent studies have shown that the fullerenes, used as electron acceptor in solar cells, induce a thermal instability of the active layer morphology. ${ }^{7,8}$ Under an annealing treatment, the conjugated polymer and the soluble $\mathrm{C}_{60}$-derivative $\mathrm{PCBM}$ demix; PCBM clustering is observed. It is expected that this change in active layer morphology has an effect on the performance of the solar cells. In this paper, we study the effect of a thermal treatment on the performance (i.e. the photovoltaic parameters) of the solar cells and link it with the changes in active layer morphology. Also, a possible improvement of the thermal stability is suggested which is based on the use of a conjugated polymer with high glass transition temperature.

\section{METHODOLOGY}

MDMO-PPV (Poly[2-methoxy-5-(3',7'-dimethyloctyloxy)-1,4-phenylene vinylene], Merck OLED) was taken as electron donor in the solar cells. As electron acceptor, PCBM ([6,6]-phenyl C61-butyric acid methyl ester, Nano-C) was used. Bulk heterojunction solar cells were prepared starting from ITO patterned $(100 \mathrm{~nm})$ glass substrates. These substrates were cleaned $10 \mathrm{~min}$ in an ultrasonic bath with successively: soap, demineralised water, acetone and boiling isopropanol. A layer of PEDOT-PSS (Bayer) of about $60 \mathrm{~nm}$ was spincoated on top of the ITO pattern after which it was annealed at $120^{\circ} \mathrm{C}$ for 10 minutes. The active layer $( \pm 120 \mathrm{~nm})$ was spincoated on top of the PEDOT-PSS from a solution of $0.5 \mathrm{wt} \%$ (with respect to the polymer) of MDMO-PPV:PCBM 1:4 in chlorobenzene. As top electrode an Al contact with a thickness of $80 \mathrm{~nm}$ was evaporated on top of the active layer. Figure 1 shows the structure of the solar cell. 


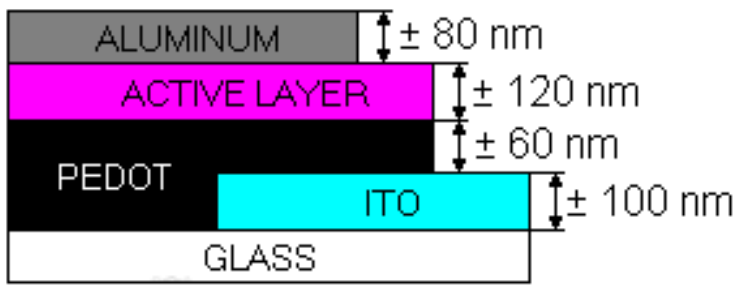

Figure 1: Side view of a solar cell.

IV-measurements were done with an Oriel solar simulator equiped with a Xenon Short Arc lamp with a power of $150 \mathrm{~W}$ to determine the photovoltaic parameters (short circuit current, open circuit voltage, fill factor and efficiency).

After the IV-characterization, the active layer of the solar cells was examined with a Transmission Electron Microscope (Philips CM12-STEM). The TEM samples were taken from the area adjacent to the Al contact, i.e. right next to the solar cells.

\section{RESULTS}

\subsection{The effect of annealing on the performance of solar cells}

Thermal ageing of the photovoltaic parameters of solar cells was examined through a three-stage experiment. Firstly, a set of identical solar cells (with an active layer of MDMO-PPV:PCBM 1:4) was prepared and immediately after preparation IV-characterization was performed to obtain the initial values of the photovoltaic parameters. Secondly, each device was annealed (at $100^{\circ} \mathrm{C}$ or $110^{\circ} \mathrm{C}$ ) for a specific time interval (between 0 and 16 hours). This was done in the dark, in a nitrogen atmosphere to prevent degradation due to UV-radiation and oxygen. As a third and final step, when all annealing treatments were finished, IV-characterization of all solar cells was redone. The final solar cell parameters were normalized with respect to the initial values. The curves representing the relative decay of the photovoltaic parameters vs. the annealing time are shown in Figure 2.

We will first discuss the curves corresponding to an annealing temperature of $100^{\circ} \mathrm{C}$ (squares in Figure 2). The first point in the curves corresponds with a solar cell that was not annealed. It was kept in the dark at room temperature during the full experiment to determine the shelf life degradation of the photovoltaic parameters. Apparently, even without a thermal treatment, there is already a small decay in the photovoltaic parameters. This indicates that even without annealing, the solar cells are not stable.

From the second point of the curves onwards, the effect of the annealing on the solar cell parameters can be seen. The annealing results in a significant decay of the solar cell parameters. The short circuit current $\left(\mathrm{I}_{\mathrm{sc}}\right)$ shows a rather exponential decay. After 16 hours of annealing, it has dropped to about $75 \%$ of its initial value. The decay in fill factor (FF) has roughly the same behaviour as the decay in $\mathrm{I}_{\mathrm{sc}}$. The open circuit voltage $\left(\mathrm{V}_{\mathrm{oc}}\right)$ seems to be less sensitive to a thermal treatment than $I_{s c}$ and FF. The efficiency $(\eta)$ of the solar cells, being proportional to the product of the other 3 photovoltaic parameters, obviously has the largest decay. Its value drops below $50 \%$ of its initial value. These results clearly show that annealing has a dramatic influence on the performance of this type of solar cells.

When the annealing temperature is raised to $110^{\circ} \mathrm{C}$ (triangles in Figure 2), the decay characteristics of the photovoltaic parameters change slightly. The small difference between the first points in the $100^{\circ} \mathrm{C}$-curve and the $110^{\circ} \mathrm{C}$-curve is caused by a different time period between the initial and final IV-characterization ( 30 hours for the $100^{\circ} \mathrm{C}$-curve vs. 42 hours for the $110^{\circ} \mathrm{C}$-curve). Looking at the further course of the curves, the decay in photovoltaic parameters occurs faster for an annealing temperature of $110^{\circ} \mathrm{C}$ than for an annealing temperature of $100^{\circ} \mathrm{C}$. This could be expected since for higher annealing temperatures, more energy is supplied and changes in the active layer can take place easier. If a rough Arrhenius analysis is performed on these results, an activation energy of around $1 \mathrm{eV}$ is obtained. As a rule of thumb: for an activation energy of $1 \mathrm{eV}$, one can expect that an increase in temperature of $10^{\circ} \mathrm{C}$ would accelerate the degradation with a factor of 2 . For a detailed Arrhenius analysis, a set of in situ experiments should be performed at various temperatures. For this purpose, at the moment an in situ equipment is being developed at our institute and more experiments are planned. 

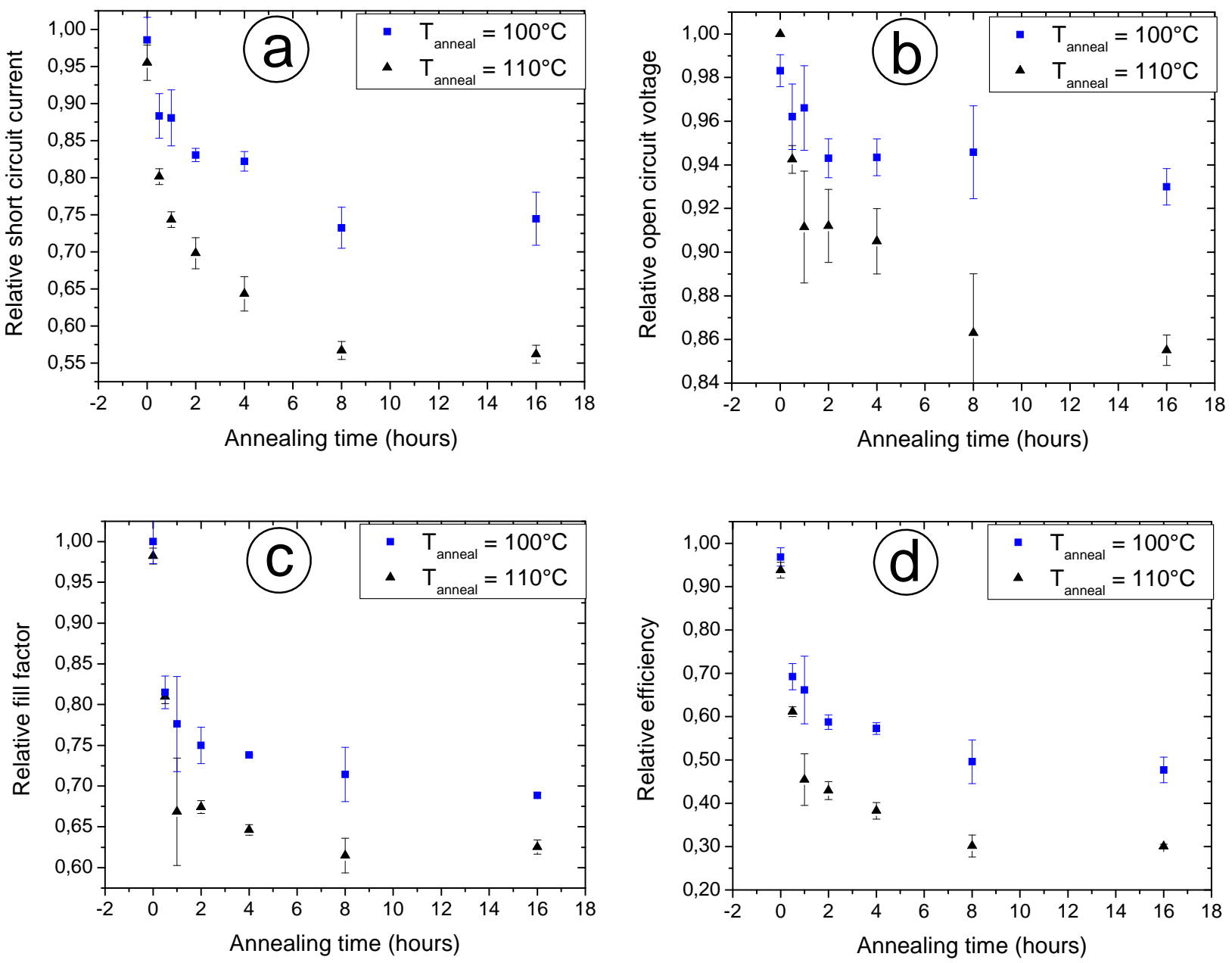

Figure 2: Decay of the relative short circuit current (a), the open circuit voltage (b), the fill factor (c) and the efficiency (d) as a result of annealing at $100^{\circ} \mathrm{C}$ (squares) and $110^{\circ} \mathrm{C}$ (triangles) of MDMO-PPV:PCBM (1:4) solar cells.

\subsection{The effect of annealing on the morphology of the active layer}

The previous paragraph showed that the performance of solar cells is affected by an annealing treatment. Now an attempt is made to link the performance decay to a morphology change of the active layer. The active layers of the solar cells mentioned in section 3.1 were investigated using TEM. Figure 3 and Figure 4 show the TEM images of the annealed films (respectively at $100^{\circ} \mathrm{C}$ and $110^{\circ} \mathrm{C}$ ) and the corresponding selected-area electron diffraction (SAED) patterns. The mass density of PCBM is higher than the mass density of MDMO-PVV. Therefore a distinction can be made between PCBM rich areas (dark spots) and areas depleted of PCBM (light areas between the spots) [8].

The non-annealed films clearly show phase separation of small (50-100 nm) PCBM nanocrystals embedded in a polymer matrix [9]. The thermal treatment of the film results in clustering and crystallization of PCBM. For an annealing temperature of $100^{\circ} \mathrm{C}$ these processes begin after 2 hours of annealing (see figure 3d). In this TEM image, a cluster of PCBM can be seen while the SAED pattern shows that crystallization has occurred. The d-spacings of the spots correspond with the values for triclinic PCBM [10]. The longer the films are annealed, the more PCBM clusters appear.

This clustering of PCBM can be an explanation for the decay in short circuit current of the solar cells. When PCBM clusters, the interface between PCBM en MDMO-PPV decreases. Therefore, the excitons, created in the MDMO-PPV, find it harder to dissociate and more recombination will take place. This results in a decrease of the short circuit current. 
Comparing Figure 3 to Figure 4, the diffusion rate of PCBM at $110^{\circ} \mathrm{C}$ happens faster than at $100^{\circ} \mathrm{C}$. For the annealing temperature of $110^{\circ} \mathrm{C}$, clusters and crystals already appear after 0.5 hour. Thus, the faster decay in photovoltaic parameters coincides with a faster morphology change.

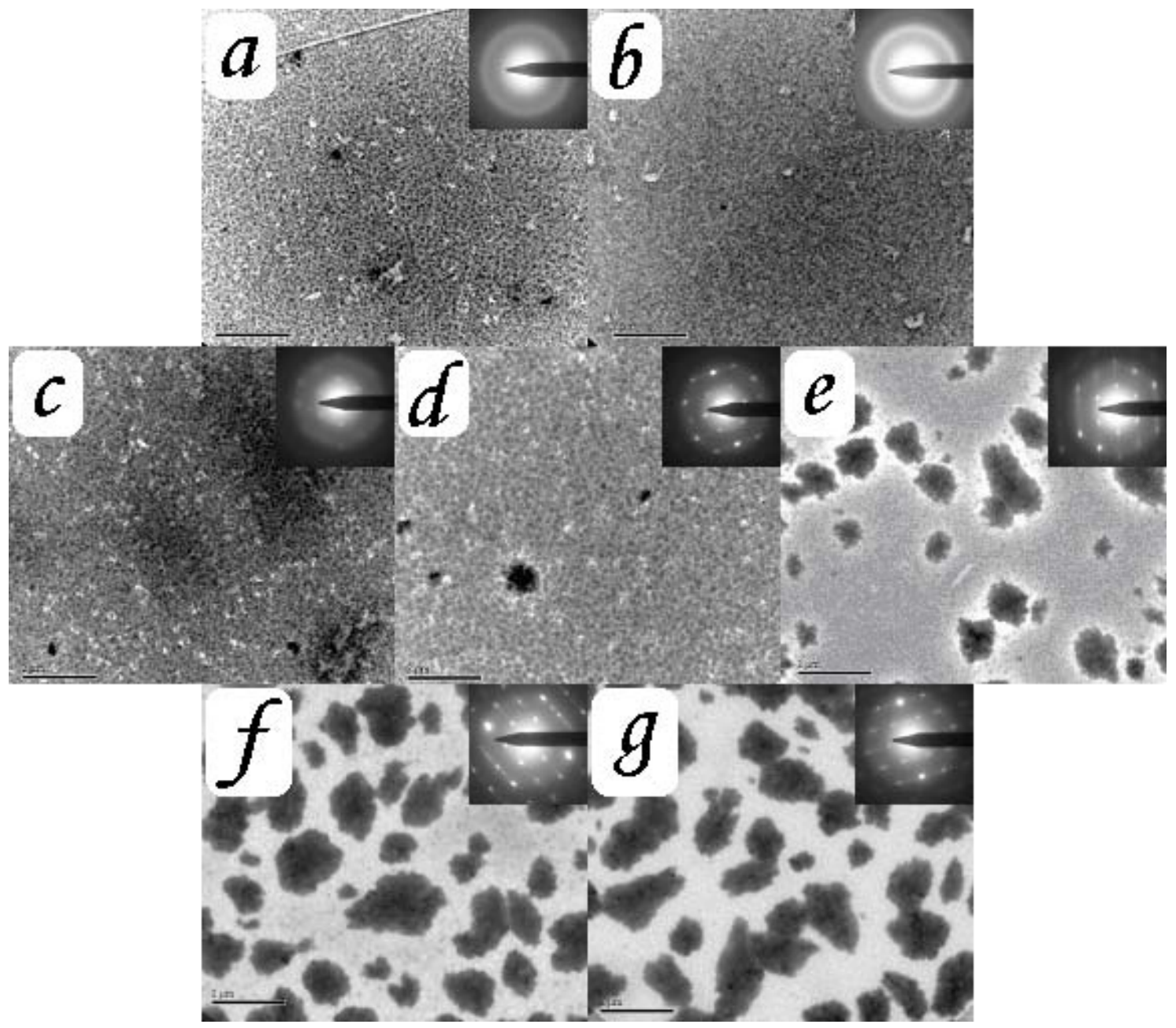

Figure 3: TEM images of the MDMO-PPV:PCBM (1:4 wt ratio) layers in solar cells. The solar cells were annealed for a) $0 \mathrm{~h}, \mathrm{~b}) 0.5 \mathrm{~h}$, c) $1 \mathrm{~h}, \mathrm{~d}) 2 \mathrm{~h}, \mathrm{e}) 4 \mathrm{~h}, \mathrm{f}) 8 \mathrm{~h}, \mathrm{~g}) 16 \mathrm{~h}$ at $100^{\circ} \mathrm{C}$ (scale bar: $\left.2 \mu \mathrm{m}\right)$. 


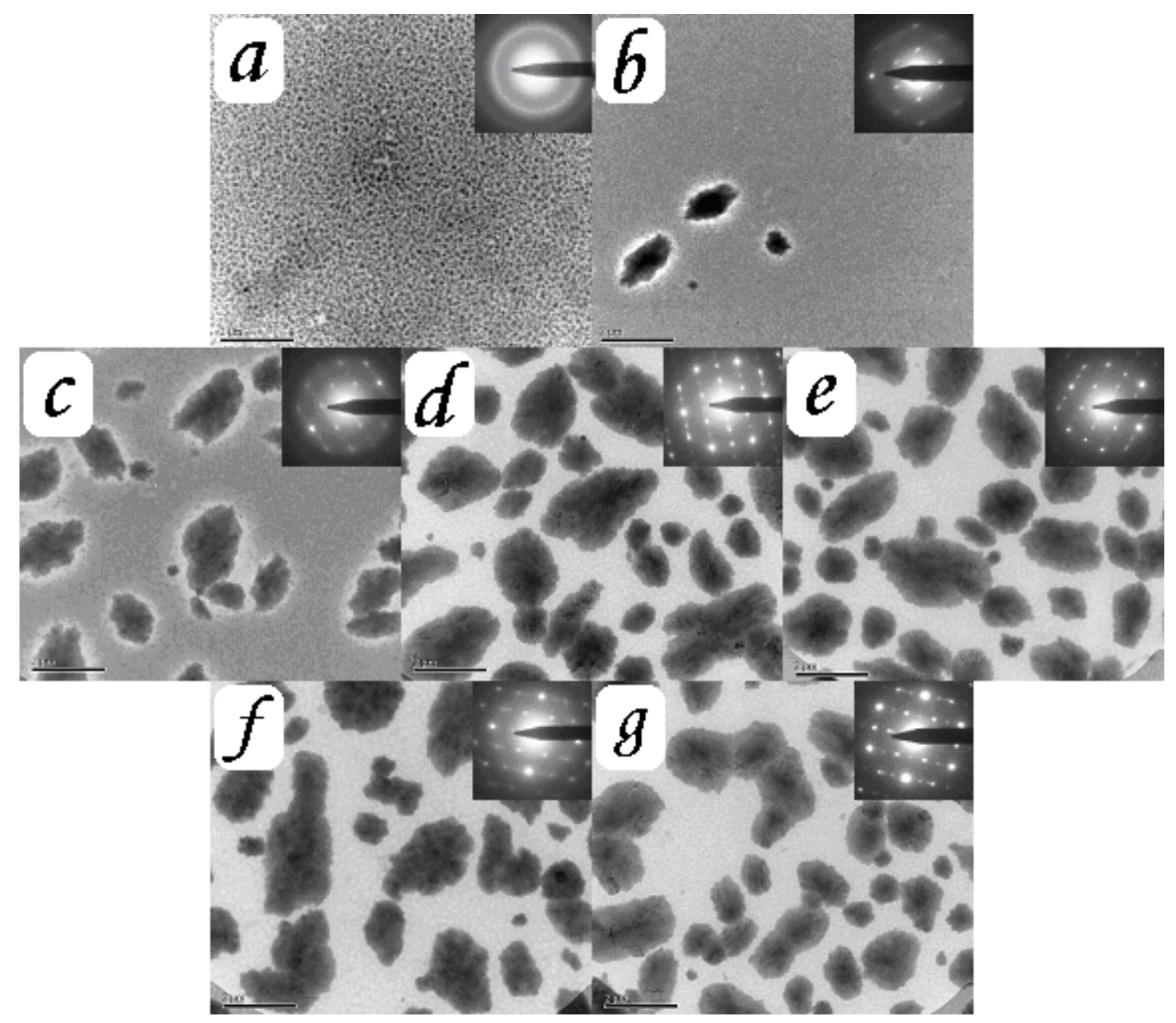

Figure 4: TEM images of the MDMO-PPV:PCBM (1:4 wt ratio) layers in solar cells. The solar cells were annealed for a) $0 \mathrm{~h}, \mathrm{~b}) 0.5 \mathrm{~h}$, c) $1 \mathrm{~h}, \mathrm{~d}) 2 \mathrm{~h}, \mathrm{e}) 4 \mathrm{~h}, \mathrm{f}) 8 \mathrm{~h}, \mathrm{~g}) 16 \mathrm{~h}$ at $110^{\circ} \mathrm{C}$ (scale bar: $2 \mu \mathrm{m}$ ).

The difference in diffusion rate can also be seen by looking at the matrix of the blend between the clusters. Figure 5 and Figure 6 show some TEM images to clarify this. After 4 hours of annealing at $100^{\circ} \mathrm{C}$ (Figure 5) the matrix around the large PCBM clusters, still consists of a homogeneous blend of PCBM nanocrystals (small dark circles) and MDMO-PPV (light area between the circles). This matrix is comparable to the initial matrix, when no annealing was performed. After 8 hours of annealing at $100^{\circ} \mathrm{C}$, the small dark PCBM areas seem to vanish and after 16 hours of annealing, all the small dark circles (nanocrystals) have disappeared. Instead, light circles are visible. It seems as though the PCBM has completely diffused out of the matrix. For an annealing temperature of $110^{\circ} \mathrm{C}$, the same phenomenon is observed but now the PCBM nanocrystals have already disappeared after 2 hours of annealing (Figure 6). 


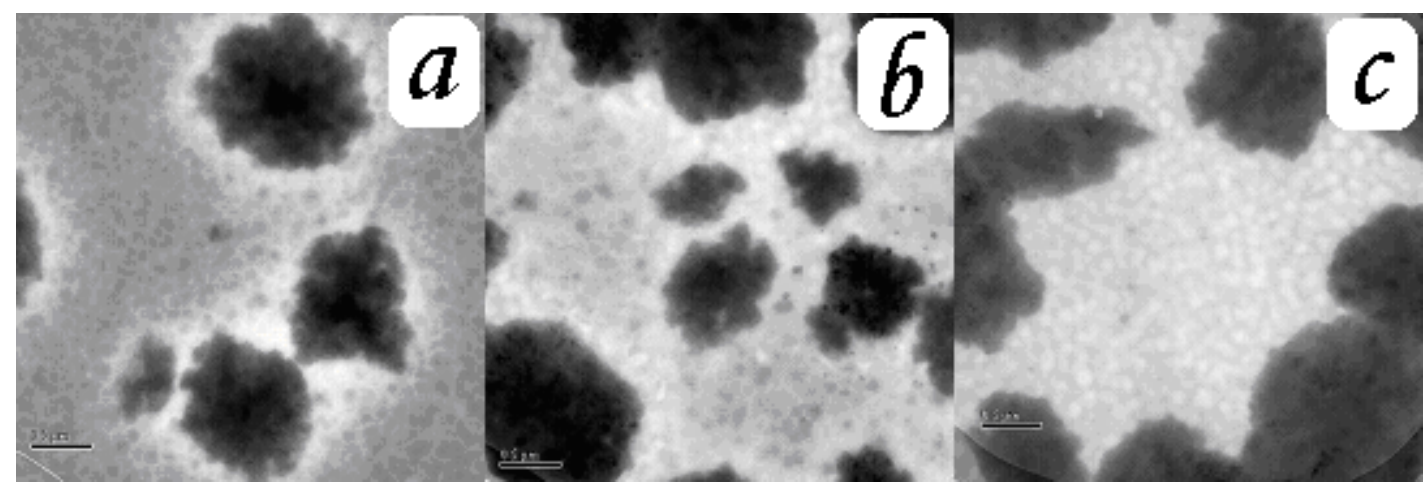

Figure 5: Matrix between the PCBM clusters after a) 4h, b) $8 \mathrm{~h}$, c) $16 \mathrm{~h}$ of annealing at $100^{\circ} \mathrm{C}$ (scale bar: $0.5 \mu \mathrm{m}$ ).

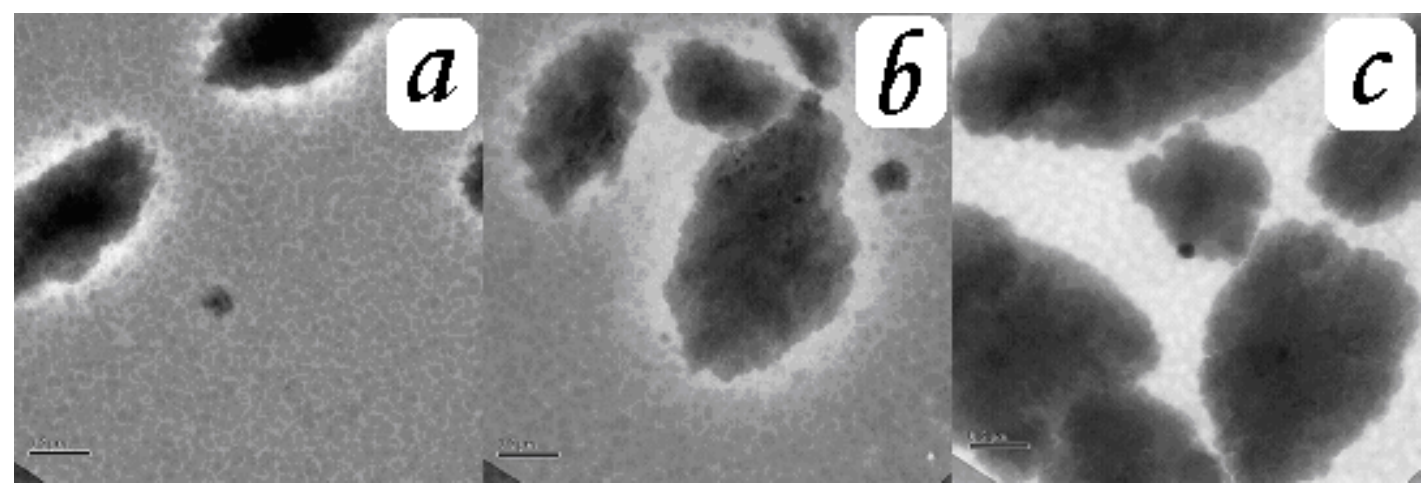

Figure 6: Matrix between the PCBM clusters after a) $0.5 \mathrm{~h}, \mathrm{~b}) 1 \mathrm{~h}, \mathrm{c}) 2 \mathrm{~h}$ of annealing at $110^{\circ} \mathrm{C}$ (scale bar: $0.5 \mu \mathrm{m}$ ).

To check whether the PCBM had really vanished from the matrix, the SAED patterns of the matrix were investigated. The residual intensity profiles of the SAED patterns of the matrix with and without the small nanocrystals are represented in Figure 7 as a function of the d-value. The SAED pattern of the area with the nanocrystals (topmost curve in Figure 7) shows peaks at d-values corresponding to PCBM [10]. For the area without the nanocrystals (bottom curve in Figure 7), the peaks have disappeared. This proves that all the PCBM has vanished from the matrix and can be found in the large clusters.

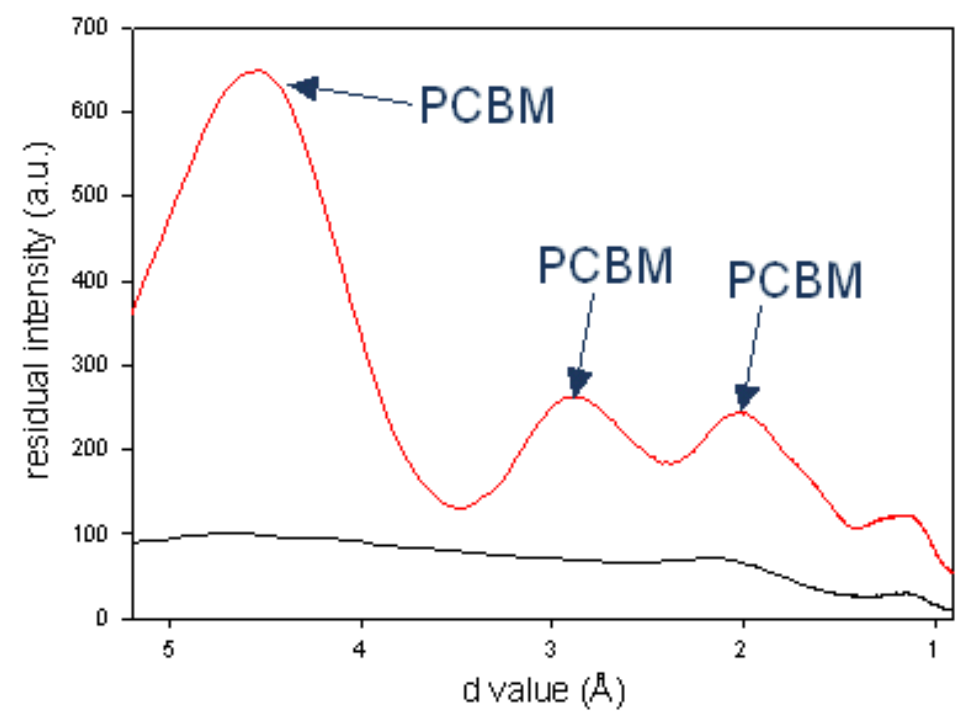

Figure 7: Residual intensity of the SAED patterns of the matrix where the PCBM-nanocrystals are still present (topmost curve) and where they have disappeared (bottom curve). 


\subsection{Thermal stability of a polymer with high glass transition temperature}

In this paragraph an alternative possibility is investigated to improve the thermal stability of solar cells, namely the use of polymers with a high glass transition temperature $\left(\mathrm{T}_{\mathrm{g}}\right)$. The MDMO-PPV used in the previous sections has a $\mathrm{T}_{\mathrm{g}}$ of about $45^{\circ} \mathrm{C}$. To test the hypothesis of a better thermal stability for polymers with a high $T_{g}$, a specially designed PPV with a glass transition temperature of about $150^{\circ} \mathrm{C}$ was supplied by Merck OLED.

Solar cells with an active layer of 'High $\mathrm{T}_{\mathrm{g}}$ PPV':PCBM 1:4 were made and the experiment with an annealing temperature of $110^{\circ} \mathrm{C}$ was repeated with these solar cells. The results are shown in Figure 8. Again, the first point of the curves corresponds with the degradation of the devices due to storage at room temperature (shelf life), while the following points are obtained through annealing at $110^{\circ} \mathrm{C}$. The decay of the photovoltaic parameters due to shelf storage ageing lies in the same range for both kinds of solar cells, well above $90 \%$ of the initial values. In the further course of the graphs, there is a clear deviation for the two different materials. Surprisingly, the short circuit current of the 'High $\mathrm{T}_{g}$ PPV' solar cells showed only a small decrease due to annealing; its value stayed above $90 \%$ of the initial value after 16 hours of annealing at $110^{\circ} \mathrm{C}$, while for MDMO-PPV based solar cells, it decreased down to less than $60 \%$ of the initial value. The decay in fill factor for both kinds of devices roughly follows the same pattern as the decay in short circuit current. This results in the fact that the overall efficiency is much more stable for 'High $\mathrm{T}_{g}$ PPV' based solar cells (a decrease down to about $80 \%$ after 16 hours of annealing) as compared to MDMO-PPV based solar cell (a decrease down to about $30 \%$ after 16 hours of annealing). These results clearly show a better thermal stability for the 'High $\mathrm{T}_{\mathrm{g}}$ PPV' solar cells.
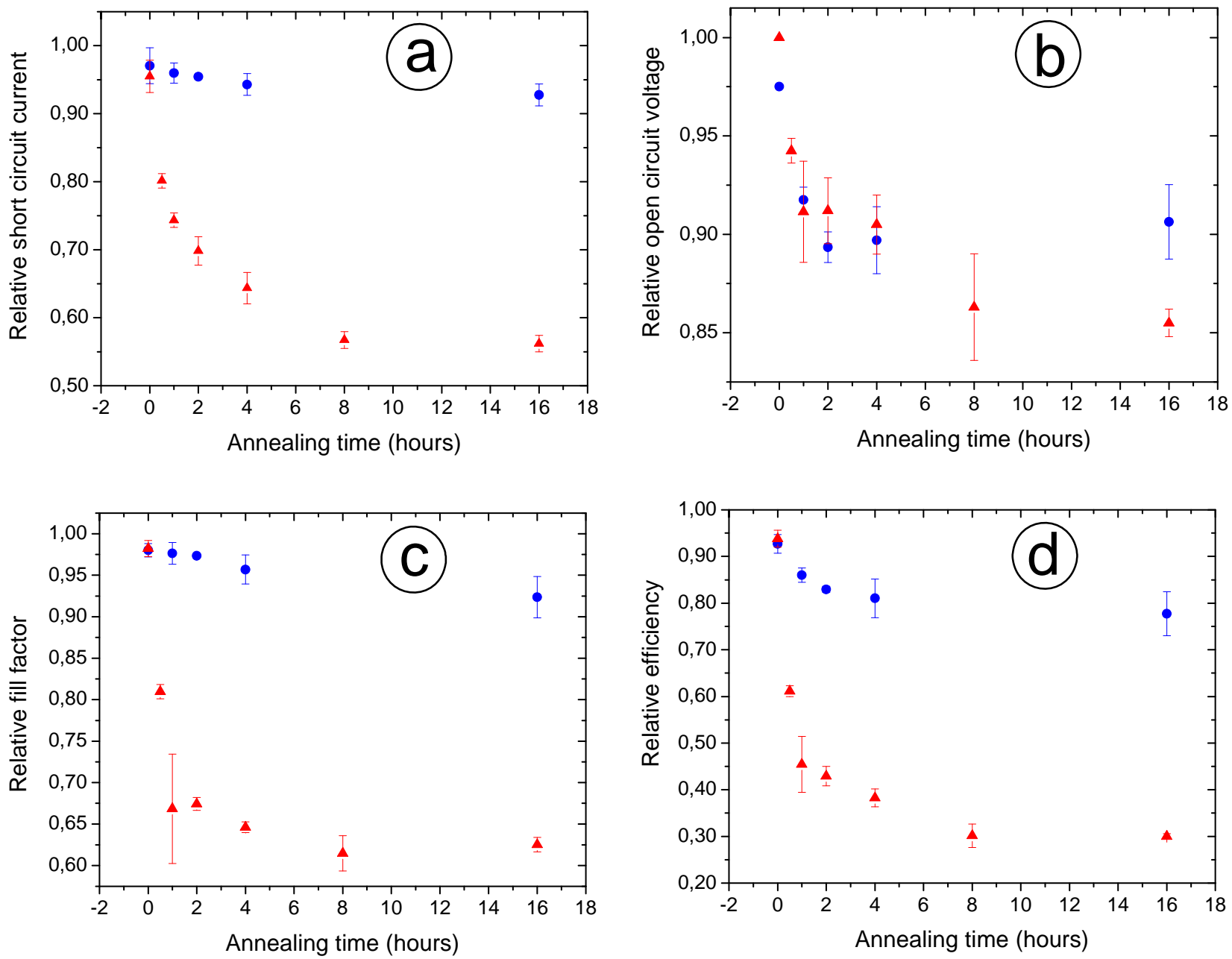

Figure 8: Decay of the relative short circuit current (a), the open circuit voltage (b), the fill factor (c) and the efficiency (d) as a result of annealing at $110^{\circ} \mathrm{C}$ for MDMO-PPV:PCBM (1:4) solar cells (triangles) and 'High $\mathrm{T}_{\mathrm{g}}$ PPV':PCBM (1:4) solar cells (circles). 
The morphology of the active layers of the high $\mathrm{T}_{\mathrm{g}}$ PPV solar cells was also examined. The TEM images are presented in Figure 9. Comparing the TEM images of the 'High $\mathrm{T}_{\mathrm{g}}$ PPV':PCBM blends with the TEM images of the MDMOPPV:PCBM blends in Figure 4 shows a clear difference in the crystallization rate of PCBM. For the MDMOPPV:PCBM blends, crystals already appeared after $0.5 \mathrm{~h}$ annealing at $110^{\circ} \mathrm{C}$. After 2 hours of annealing, the crystallization process seemed complete. For the 'High $T_{g}$ PPV':PCBM blends, crystallization has just begun after 16 hours of annealing. These TEM images confirm the IV measurements in Figure 8: a more stable performance of photovoltaic parameters coincides with a more stable active layer morphology.

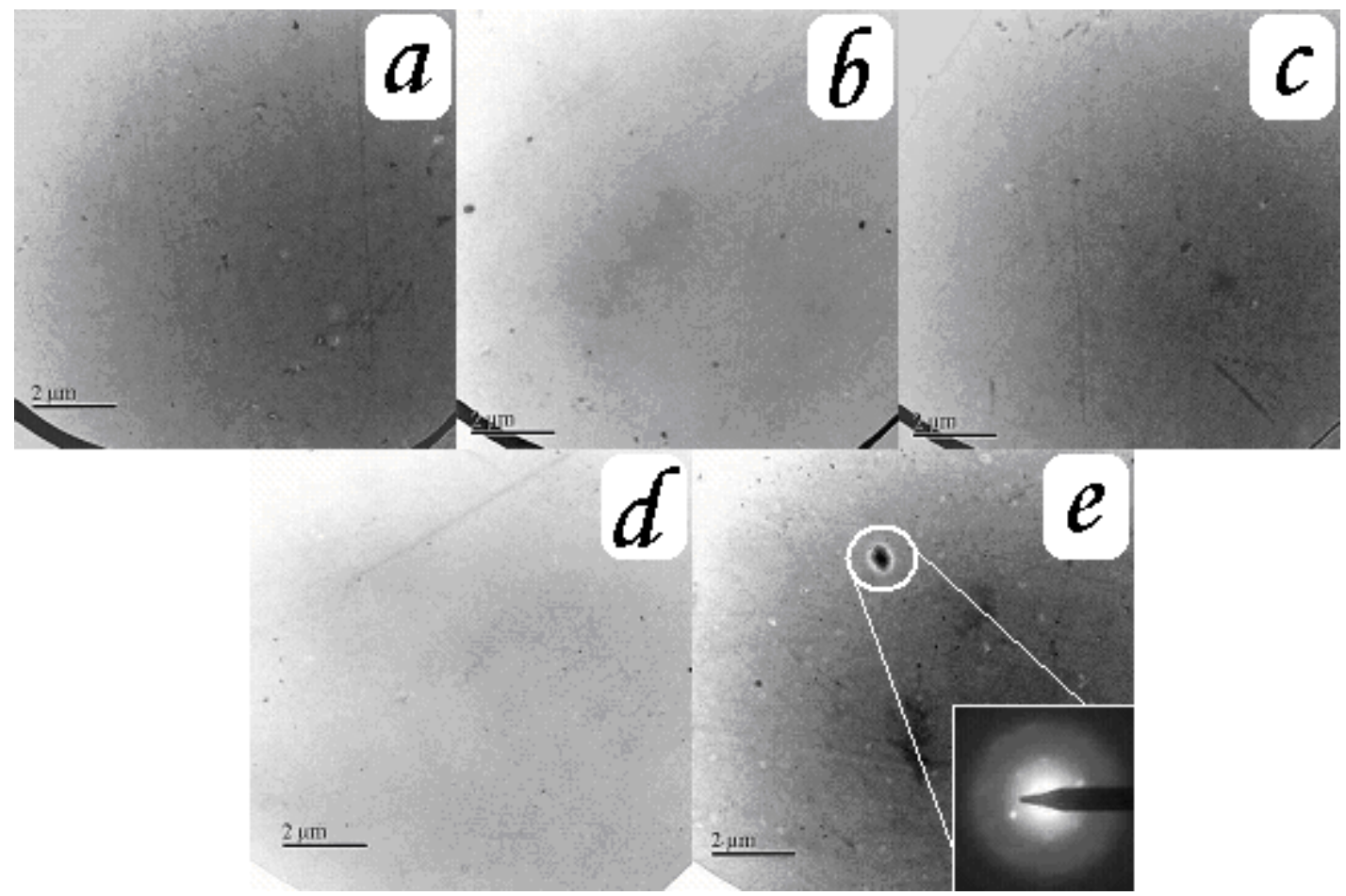

Figure 9: TEM images of the active layer of 'High $\mathrm{T}_{\mathrm{g}}$ PPV':PCBM 1:4 solar cells. The solar cells were annealed at $110^{\circ} \mathrm{C}$ for a) $0 \mathrm{~h}, \mathrm{~b}$ ) $1 \mathrm{~h}, \mathrm{c}) 2 \mathrm{~h}, \mathrm{~d}) 4 \mathrm{~h}, \mathrm{e}) 16 \mathrm{~h}$ (scale bar: $2 \mu \mathrm{m}$ ).

\section{CONCLUSIONS}

Bulk heterojunction solar cells based on MDMO-PPV showed significant decays in photovoltaic parameters when a thermal treatment $\left(100^{\circ} \mathrm{C}-110^{\circ} \mathrm{C}\right)$ was applied. The higher the annealing temperature, the faster the decay rate. The decay in short circuit current could be linked to a change in active layer morphology, where PCBM clustering occurred during annealing. A possible improvement of the thermal stability of organic solar cells was found in the use of a conjugated polymer with high glass transition temperature.

\section{ACKOWLEDGEMENTS}

The research was (partly) carried out in the framework of the IWT-project 030220 "Nanosolar", the FWO-project G025204 and the European project Molycell. We thank Dr. H. Becker of Merck OLED Materials GmbH for the supply of the 'High $\mathrm{T}_{\mathrm{g}}$ PPV'. 


\section{REFERENCES}

1. W. Ma, C. Yang, X. Gong, K. Lee, A.J. Heeger, Adv. Funct. Mater. 2005, 15, 1617

2. H. Neugebauer, C.J. Brabec, J.C. Hummelen, R.A.J. Janssen, N.S. Sariciftci, Synth. Met. 1999, 102, 1002

3. $\quad$ F. Padinger, T. Fromherz, P. Denk, C.J. Brabec, J. Zettner, T. Hierl, N.S. Sariciftci, Synth. Met. 2001, 121, 1605

4. J.M. Kroon, M.M. Wienk, W.J.H. Verhees, J.C. Hummelen, Thin Solid Films 2002, 403-404, 223

5. F.C. Krebs, J.E. Carlé, N. Cruys-Bagger, M. Andersen, M.R. Lilliedal, M.A. Hammond, S. Hvidt, Sol. Energy Mater. Sol. Cells 2005, 86, 499

6. $\quad$ S. Schuller, P. Schilinsky, J. Hauch, C.J. Brabec, Appl. Phys. A. 2004, 79, 37

7. X. Yang, J.K.J. van Duren, M.R. Rispens, J.C. Hummelen, R.A.J. Janssen, M.A.J. Michels, J. Loos, Adv. Mater. 2004, 16, 802

8. $\quad$ X. Yang, J.K.J. van Duren, R.A.J. Janssen, M.A.J. Michels, J. Loos, Macromolecules 2004, 37, 2151

9 T. Martens, J. D’Haen, T. Munters, Z. Beelen, L. Goris, J. Manca, M. D’Olieslaeger, D. Vanderzande, L. De Schepper, R. Andriessen, Synthetic Metals 2003, 138, 243

10. M.T. Rispens, A. Meetsma, R. Rittberger, C.J. Brabec, N.S. Sariciftci, J.C. Hummelen, Chemical Communications 2003,2116 